\title{
Impediments of Traditional Painting Souvenir Development in and around the Historic of Gondar, Ethiopia
}

\author{
Leul Yohannes
}

MA, Tourism and Heritage Management, Department of Tourism Management, College of Business and Economics, University of Gondar, Ethiopia

\begin{abstract}
Other than its huge socio-economic benefits, a well-developed handicraft industry usually helps a destination to draw the attention of visitors easily. However, the development of souvenir handcrafts is being challenged by various contextual factors derived from socio-economic situations of each tourist destinations. So, this research examined impediments of painting souvenir development in North West Ethiopia taking the case from the historic city of Gondar. Qualitative data were collected through the use of key informant interview and document analysis to complement each other. Relevant respondents from traditional painting artisans, souvenir shop owners/managers and culture and tourism experts were sampled through data saturation approach. The interpretation of data used a thematic descriptive approach that utilizes a theme summary data and unattributed quotes to illustrate dominant issues in respondents' own words. The research disclosed that the development of painting souvenir handcraft in and around Gondar city has been impeded by poor startup capital, weak marketing strategy, poor technology transfer system, and weak capacity building intervention together with the disjointed bargaining power of artisans. Hence, attention should be towards addressing these challenges as far as the issue of traditional painting souvenir development in and around the historic city of Gondar is concerned.
\end{abstract}

Keywords: Painting Souvenir, Souvenir-handcraft, Traditional Painting, Historic City of Gondar

\section{Background and Rationale}

Tourism nowadays is one of the major and most imperative industries in the world in terms of employment creation and generation of foreign revenue (UNDP, 2011). It contributes $9 \%$ of the global GDP, $30 \%$ of the world's export services and one in every 11 jobs worldwide (UNWTO, 2015). As industry it is a new phenomenon that consists of many complex and interdependent components. These components could be classified roughly into transportation, hospitality, attraction, travel agency-tour operation, and shopping service, etc. Being a shopping service component of the industry, souvenir shopping provides a variety of benefits both to tourists and host communities. For instance, tourists are eager to take something as memento from trip for testimony of their visit and experience. In this regard, souvenirs and their associated memories help tourists participate in non regular experiences, expand their worldview, differentiate or integrate the self with others (Smith and Reid, 1994).

As it has meaningful values, memories, and feelings attached to it, the acquisition of souvenirs is not just the collection of objects, but of memories (Smith and Reid, 1994). On the other hand, being a tangible part of the tourism experience; souvenirs provide an excellent prospect to worldwide advertising with a potentially rewarding economic activity (Holder, 1989). Because they are objects that one touches, reflects on, and shows others. To acquire a souvenir is to assure that one has achieved something or been somewhere of significance (Boynton, 1986). That is why souvenir shopping opportunities are supposed as a major attraction that magnetizes tourists to less developed countries (Keown, 1989). It has even become a solution for tourism marketing and promotion problems (JansenVerbeke, 1990).
Though the important value of souvenir handcrafts, their sustainability in many parts of world has been challenged by various contextual factors. For instance, according to Bal and Dash (2010) market for souvenirs is dependent on the market demand of developed countries, as majority of the handicrafts are highly produced in less developed countries. In this regard, a study conducted by Manzoor (1991) also disclosed that the effectiveness of market research as the most important determinant factor in the sustainability of souvenir handcrafts development. Scholars such as Girón etal, (2007) furthermore mentioned the stagnated skill development among artisans, the availability of raw materials, and the introduction of industrialization and globalization as challenge for the growth and transformation of the sector.

Empirical evidences from other countries also identified additional factors as decisive sustainability determinants of souvenir handcrafts development. For example, study by Nayak and Green Field (1994) stated that Government agencies' support, policy and regulation infrastructures, managerial capacity, and relationships with the financial sector are issues to be addressed while dealing with the sustainability of micro and small scale enterprises such as souvenir handcrafts. In addition, Baum, (1999) identified institutional help as important determinant to overcome the intrinsic disadvantages and avert failure of micro and small scale enterprises. Empirical evidences still argue that the success of micro and small scale enterprise is also dependent on government regulatory legislations (Thomas, 1995). Besides, high rates of business failure, lack of formal managerial practice, and lack of financial awareness have discouraged banks from dealing with micro and small scale tourism firms such as souvenir handcrafts (Taylor, Simpson and Howie, 1998). 


\section{International Journal of Science and Research (IJSR) \\ ISSN (Online): 2319-7064}

Index Copernicus Value (2013): 6.14 | Impact Factor (2014): 5.611

However, all of the above empirical evidences are from the socioeconomic context of other tourism destinations out of Ethiopia. In addition, these studies are too general in addressing the issue of each souvenir handcrafts such as traditional painting souvenirs. Hence, it is wise to deeply analysis the issue from each souvenir handcrafts perspective and from the Ethiopian socioeconomic context so that souvenir handcraft development actors could pass an informed decision and act according to their local context. Because the context in Ethiopia in general and the context in North West Ethiopia in particular may not be identical to the context where the above research works had been conducted. So, this research was intended to identify factors that impede the development of traditional painting souvenir in North West Ethiopia taking the case from the historic city of Gondar.

The reason why this study was conducted in and around Gondar City relates to the area's tourism and painting souvenir development potential. Because Gondar area is the leading national hubs of Ethiopian traditional painting practices (Pankhurst, 1967). Hence, study on major impediments of this precious art is very much relevant for the sustainable development of souvenir tourism in the area. At the same time, being a unique local crafts, the development of painting souvenir could help the area draw the attention of more number of tourists.

\section{Methodology}

A cross sectional survey approach sourced through document analysis and key informant interview of painting artisans, souvenir shop managers/owners, and culture and tourism experts was employed. As traditional artisans are doing painting works through informal home based business, finding the appropriate respondents were very much difficult. Hence, purposive snow ball sampling was employed. In addition, purposive sampling was used to sample appropriate souvenir shop managers/owners, and culture and tourism experts. Interview guide was constituted by items from literature, and pre-test comments. All of available documents (audio and visual types) were consulted.

The interpretation of the collected data was analyzed thematically. In this case the interview results were repeatedly and thoroughly read so as to gain the major themes of each respondent. Utilization of summary data and unattributed quotes to illustrate dominant issues in respondents' own words was also employed. The processes of transcribing /interpreting from Amharic, local language, to English as well as identifying themes, coding and clustering was carried out.

\section{Results of the Study}

A total of 31 respondents (18 Traditional Painting Artisans, 6 Souvenir-shop Managers/Owners, and 7 Culture and Tourism Experts) were sampled through the principle of data saturation. Survey on the profile of respondents illustrated that almost all the traditional painting artisans are operating at home based informal business.
Table 1: Profile of Respondents

\begin{tabular}{|l|c|c|}
\hline \multicolumn{1}{|c|}{$S / n$} & Type of Respondents & Number \\
\hline 1. & Traditional Painting Artisans & 18 \\
\hline 2. & Souvenir-shop Managers/owners & 6 \\
\hline 3. & Culture and Tourism Experts & 7 \\
\hline \multicolumn{2}{|c|}{ Total Respondents } & $\mathbf{3 1}$ \\
\hline
\end{tabular}

According to respondents the development of painting souvenir has been challenged by various factors. These are related to start up capital, marketing strategy, technology transfer mechanism, collective bargaining power, and capacity building intervention.

Startup Capital and Working Space: The interview data verified access to finance and securing startup capital as one of the most important impediments of souvenir development in Gondar area. Respondents said that majority of the traditional painting artisans are economically marginalized church scholars, and people with disabilities. Hence, they are extremely poor to fulfill the minimum requirement that local micro banks asks for. In addition, their marginalized socio-economic status hindered them from accessioning appropriate working space. This is parallel to the report by Ageba and Ameha (2004).

Marketing Strategy: Data from interview disclosed that the both artisans and souvenir shop managers have problem in identifying their customer wants, producing the appropriate product and building proper relationships with their customers. This is an important bottle neck on sustainability of enterprises as the advocacy of Hooley etal, (2002) stated. Almost all the artisans have no marketing plan. Majority of the souvenir shop managers depend on the success and failure history of their competitors as marketing strategy. The more the success of their competitors, the better marking strategy they perceive it. Hence, parallel to the study conducted by Manzoor (1991) market research is the most important challenge for sustainability of painting souvenir handcrafts in the study area.

Technology Transfer Mechanism: Respondents argued that artisans' skill is stagnated as there is no new innovative technology transfer design. "The skill transfer mechanism is too traditional and infective" said Mr. Zewdu, senior expert at Gondar City Culture and Tourism Department. Most of the respondents agreed that a skill from their forefathers is degrading from time to time due to poor technology transfer mechanism.

Almost all respondents agreed that the economic value of being a traditional painting artisan is much lesser than the economic value of labor and time exerted to learn it. Due to this, said Zewdu, "the new generation is losing interest towards painting and going to other profession for a livelihood". This is due to lack of appropriate mechanism to promote and transfer the indigenous painting technology for generations to come.

Collective Bargaining Power: All the respondents agreed that cooperation among artisans and other concerned bodies such as traders, government and non-government organizations is almost none. They replied that not only establishing a stakeholder's forum but also establishing the 


\section{International Journal of Science and Research (IJSR) \\ ISSN (Online): 2319-7064 \\ Index Copernicus Value (2013): 6.14 | Impact Factor (2014): 5.611}

artisans association is at its lowest stage. "Till now we have no association" said Yehuala, a senior traditional painting artisan. Hence, lack of our collective bargaining power both for artisans and traders is another bottle neck.

Capacity Building Support: Data from respondents disclosed that no appropriate training has been delivered to artisans and souvenir shop managers. Hence, their capacity in terms of production, marketing, and entrepreneurship is found to be poor. This is a severe challenge in assuring the sustainable development of the souvenir business. In this regard, the 2003 Ethiopian Industrial Development Strategy identified training as institutional support areas for the success of micro and small scale enterprises. Parallel to this a study by Baum (1999) and Lee-Ross (1998) strongly argued that souvenir handicraft as part of micro and small scale tourism enterprises requires capacity building training to overcome their intrinsic disadvantages and avert failure. So, attention should be given towards building the capacity of fledgling artisans through consecutive capacity building intervention.

In conclusion, attention should be given towards alleviating the above stated challenges as far as the issue of sustainable painting souvenir development in Gondar area is concerned.

\section{References}

[1] Bal, R. K. \& Dash, M. (2010). A Study on Factors Determining Buying Behavior of Handicraft Items With Reference to Handicrafts of Orissa. IUP Journal of Management Research, 2 (2), 24 - 34.

[2] Baum, T. (1999). Human resource management in tourism's small business sector: Policy dimensions, in Lee-Ross, D. (ed.) HRM in Tourism and Hospitality: International Perspectives on Small to Medium-sized Enterprises, Cassell, London, pp. 3-16.

[3] Boynton, L., (1986). The Effect of Tourism on Amish Quilting Design. Annals of Tourism Research, 13(3): 451-465.

[4] Ghosh, A., (2012). Triggering Innovation and Creativity in Traditional Handicrafts Sectors - An Indian Perspective. Global Institute of Management \& Technolog, 8 (1), p $67-71$.

[5] Girón, J., P., H., Hernández, M., L., D. and Castañeda, M., C. (2007). Strategy and factors for success: The Mexican handicraft sector. Performance Improvement, $46(8), 16-26$.

[6] Holder, J., (1989). Tourism and the future of Caribbean handicraft, Tourism management, December: 310-314.

[7] Jansen-Verbeke, M., (1991). Leisure shopping: A magic Concept for the tourism Industry, Tourism management, 12:9-14.

[8] Keown, Charles F. (1989). A Model of Tourists' Propensity to Buy: The Case of Japanese Visitors to Hawaii. Journal of Travel Research 27(3):31-34.

[9] Manzoor, Shah, (1991). Export Marketing of Kashmir Handicraft Industry. Unpublished Ph.D. Thesis in the University of Kashmir.

[10] Nayak, A. and Greenfield, S. (1994). The use of management accounting information for managing micro businesses, in Hughes, A. and Story, D.J. (eds)
Finance and the Small Firm, Routledge, London, pp. 167-183.

[11] Pankrhust, R. K. L. (1967). Notes for history of Gondar. The Ethiopian Royal Chronicle, Addis Ababa

[12] Smith,S. L. J., and L. J. N, Reid, (1994). Souvenirs of Tourism Scholarship. Research Notes and Reports

[13] Taylor, S., Simpson, J. and Howie, H. (1998). Financing small businesses, in Thomas, R. (ed.) The Management of Small Tourism \& Hospitality Firms, Cassell, London, pp. 58-77.

[14] Thomas, R. (1995). Public policy and small hospitality firms, International Journal of Contemporary Hospitality Management

[15] United Nations Environment Program (UNDP), 2011. Tourism and Poverty Reduction Strategies in the Integrated Framework for Least Developed Countries; New Guinea

[16] United Nation World Tourism Organization (2015). UNWTO Tourism Highlights. Madrid. 